\title{
Technè
}

La science au service de l'histoire de l'art et de la préservation des biens culturels

47 | 2019

Bernard Palissy : nouveaux regards sur la céramique française auX $\mathrm{XVI}{ }^{\mathrm{e}}$ et $\mathrm{XVII}{ }^{\mathrm{e}}$ siècles

\section{Experimenting in the Material World and on Paper in sixteenth-century France}

La démarche expérimentale en pratique et sur papier dans la France du XVI siècle

\section{Pamela H. Smith}

\section{(2) OpenEdition}

\section{Journals}

Electronic version

URL: http://journals.openedition.org/techne/1424

DOI: 10.4000/techne.1424

ISSN: 2534-5168

\section{Publisher}

C2RMF

Printed version

Date of publication: 1 June 2019

Number of pages: 18-29

ISBN: 978-2-11-152830-7

ISSN: 1254-7867

\section{Electronic reference}

Pamela H. Smith, «Experimenting in the Material World and on Paper in sixteenth-century France », Technè [Online], 47 | 2019, Online since 01 June 2020, connection on 23 July 2020. URL : http:// journals.openedition.org/techne/1424 ; DOI : https://doi.org/10.4000/techne.1424

\section{cc)}

La revue Technè. La science au service de l'histoire de l'art et de la préservation des biens culturels est mise à disposition selon les termes de la Licence Creative Commons Attribution - Pas d'Utilisation Commerciale - Pas de Modification 4.0 International. 


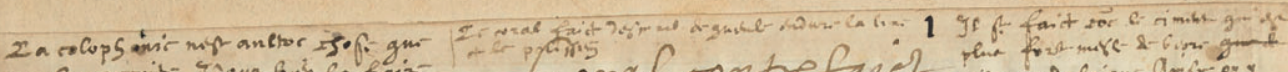

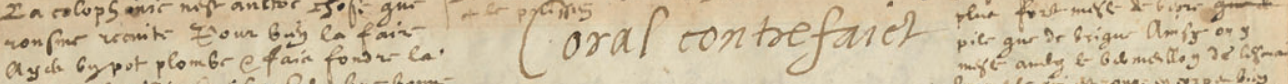

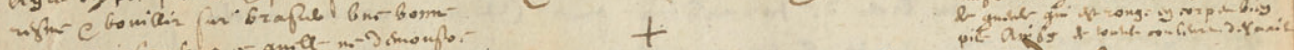

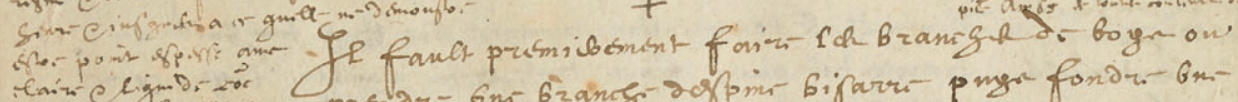

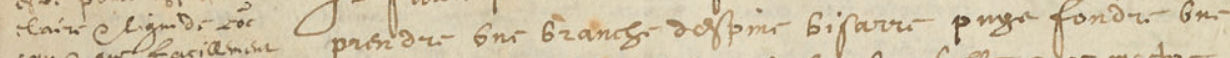

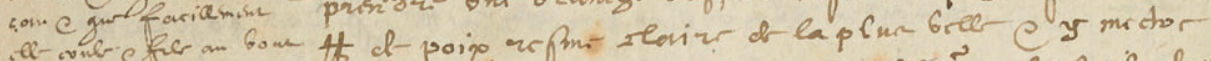

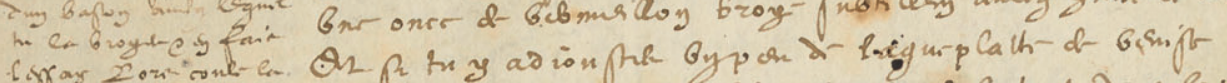

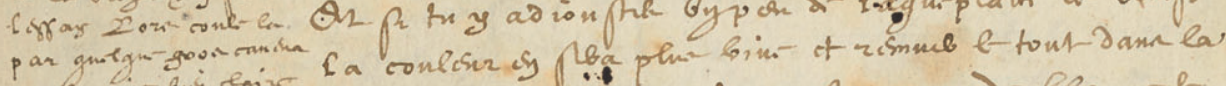

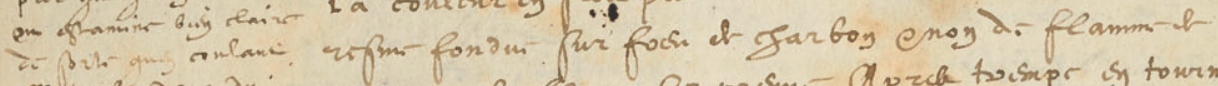

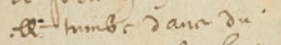
6 miang $-e-\ln x$ for

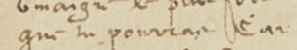
Ce-6migigur cong Jom

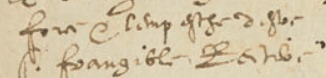

tearsing o. tori:-

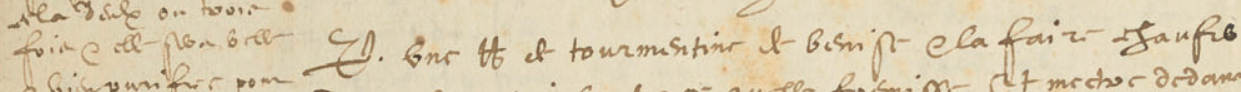

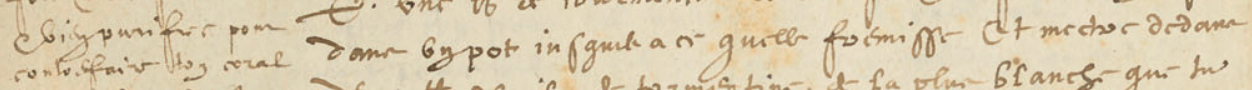
Tn porbeg miscab fa. gnarte par hit is maptipasmer ta zon por punifu. pour la wioror plow fiem

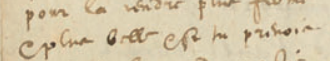

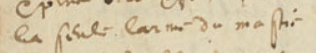
tant mike poovir man. il posit toop cong rovfor e Gomation

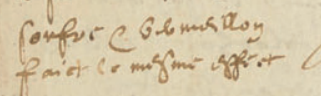

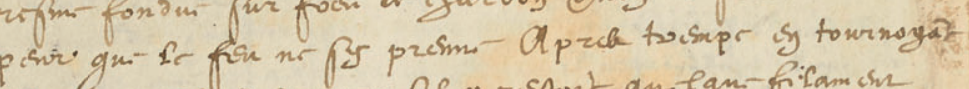

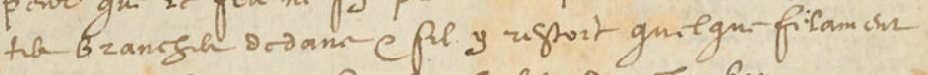
tourn \&a 6rang- us la galcer an jarboy.

\section{Cermis pour tableauir}

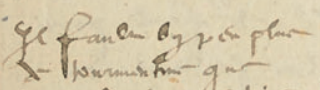

agie $\mathbf{X}-$ how hos hin-

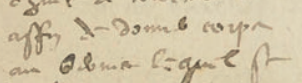
coibt-nuged a en l-voigh nits 2 . eqgesor phim de:themgin of a en ga $b^{2}$ icy-isperit Vianlemp a gripr. O.j $x-B .6$ mif par pom fain conn- CQ bublate, ar ate.

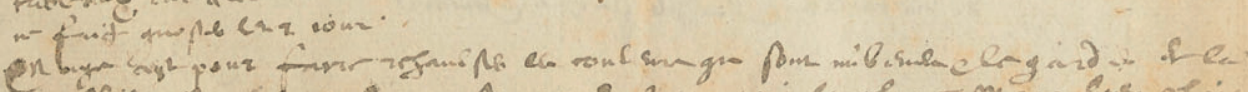

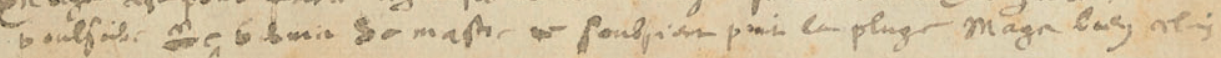
ofure norfum 
Pamela H. Smith

\section{Experimenting in the Material World and on Paper in sixteenth-century France}

La démarche expérimentale en pratique et sur papier dans la France du Xvi ${ }^{\mathrm{e}}$ siècle

\begin{abstract}
Hands-on experimentation did not begin in the natural scientific laboratory of the nineteenth century; it is instead a characteristic part of craft processes wherever and whenever they have been carried out - whether the bronze hearths of the prehistoric Near East, the furniture ateliers of the Ancien Régime, or in the kilns of the Saintonge, where Bernard Palissy labored so hard to imitate porcelain. A contemporary manuscript, BnF Ms. Fr. 640, gives remarkable insight into this constant experimentation of the artisan in the workshop. It also highlights the experimentation on paper that Palissy and other craftspeople engaged in during the sixteenth century.

Keywords. Artisan, art of the earth, experiment, experimental philosophy, grotto, Jamnitzer, Wenzel, life cast, lizards, Making and Knowing Project, Ms. Fr. 640, recipes.
\end{abstract}

Résumé. La démarche expérimentale ne commence pas dans les laboratoires scientifiques $d u X I X^{e}$ siècle, mais fait partie intégrante du processus de création quel que soit le lieu ou l'époque où il est mené, qu'il s'agisse des foyers de bronziers du Proche-Orient préhistorique, des ateliers d'ébénistes de l'Ancien Régime ou des fours de la Saintonge, où Bernard Palissy poursuivit ses efforts pour imiter la porcelaine. Un manuscrit de cette époque (BnF Ms. Fr. 640) apporte un remarquable éclairage sur cette expérimentation constante de l'artisan au sein de son atelier. Il souligne également l'importance de l'expérimentation sur papier dont témoignent les écrits de Palissy et d'autres artisans $d u X_{V I} I^{e}$ siècle.

Mots-clés. Artisan, art de la terre, expérimentation, philosophie expérimentale, grotte, Wenzel Jamnitzer, moulage sur le vif, lézards, Making and Knowing Project, Ms. Fr. 640, recettes.
In Discours admirables de la nature des eaux $\mathcal{E}$ fontaines tant naturelles qu'artificielles, des métaux, des sels $\mathcal{E}$ salines, des pierres, des terres, du feu Ẽ des émaux... (1580) (Admirable Discourses on the Nature of Waters and Fountains, Either Natural or Artificial, on Metals, Salts and Salines, on Rocks, Earths, Fire and Enamels), Palissy recounts his difficult years of experimentation in the "art of the earth," as he sought the secret of porcelain. He worked incessantly, testing and trying glazes, consuming his family's funds, harming his own health, and destroying his good name. In his antagonistic dialogue between "Theorique" and "Practique" (Theory and Practice), Palissy recounts that

"Je pilois en ces jours là de toutes les matieres que je pouvois penser qui pouroyent faire quelque chose, \& les ayant pilées \& broyées j'achetois une quantité de pots de terre, \& apres les avoir mis en pieces je mettois des matieres que j'avois broyées, dessus icelles, \& les ayant marquées je mettois en escrit a part les drogues que j'avois mis sus chacune d'icelles, pour mémoire puis ayant fait un forneau a ma fantasie, je mettois cuire lesdittes pieces pour voir si mes drogues pouroyent faire quelque couleur de blanc: car je ne cherchois autre esmail que le blanc estoit le fondement de tous les autres esmaux. Or par ce que je n'avois jamais veu cuire terre, ny ne scavois a quel degré de feu ledit esmail se devoit fondre, il m'estoit impossible de pouvoir rien faire par ce moyen, ores que mes drogues eussent esté bonnes, parce qu'aucune fois la chose avoit trop chaufé \& autre fois trop peu, \& quant lesdites matieres estoyent trop peu cuittes ou bruleés, je ne pouvois rien juger de la cause pourquoy je ne faisois rien de bon, mais en donnois le blasme aux matieres, combien que quelque fois la chose se fut peut estre trouvée bone, ou pour le moins j'eusse trouvé quelque indice pour parvenir à mon intention, si j'eusse peu faire le feu selon que les matieres le requeroyent (...). Or m'estant ainsi abuzé plusieurs fois avec grand frais \& labeurs, j'estois tous les jours à piler \& broyer nouvelles matieres \& construire nouveaux fourneaux, avec grande despence d'argent \& consommation de bois \& de temps. Quand j'eus bastelé plusieurs années ainsi imprudemment avec tristesse \& soupirs $(\ldots)^{1}$. [M] ais quand ce fut à la seconde cuisson je receus des tristesses \& labeurs tels que nul homme ne voudroit croire ${ }^{2}$." 
("I crushed, in those days, all sorts of materials that I thought could be used, and after having pounded and crushed them, I would buy a number of earthen pots, and after breaking them to pieces, I would put the things I had crushed on them, and after marking them, I would write down the drugs I had put on each one, as a reminder; then after I had built a kiln to my liking, I would put these pieces to bake to see if my drugs could produce some white color, for I was looking for no other enamel than white: because I had heard that white was the basis of all other enamels. Now, since I had never seen earth fired, and did not know at what heat this enamel would melt, I could do nothing in this way, even if my drugs had been good, for at one time my work had been heated too much, at others too little, and when these materials were too little baked or burned, I could not find out why I was making nothing good, but put the blame on the materials, although sometimes the work might have been good, or at least I could have got some hint toward achieving my goal if I could have controlled fire according to the requirements of the materials (...). But, after making many mistakes, with much expense and effort, I would pound and crush new material every day and build new kilns, at great cost in money and loss of wood and time. When I had thus blundered about unwisely for several years, with sadness and sighing $(\ldots)^{3}$. [W] hen it came to the second firing, I had sorrows and labors such as no man would believe ${ }^{4}$.")

He ends his account by noting that "Les fautes que j'ay faites en mettant mes esmaux en doze, m'ont plus apprins que non pas les choses qui se sont bien trouvées : parquoy je suis d'advis que tu travailles pour chercher laditte doze, aussi bien que j'ay fait, autrement tu aurois trop bon marché de la science 5 " ("The mistakes I made while I found out the dose for my enamels taught me more than the things that were easy to learn, therefore I judge that you should work to find this dose, just as I have done; otherwise you would esteem the knowledge too lightly6"), to which Theorique replies: "Tu me fais trouver les choses merveilleusement bonnes : si c'estoit quelque grande science, de laquelle on eut grande necessité, tu l'a ferois bien trouver bonne : veu que tu estimes si fort un art mechanique, du quel on se peut passer aisément"." ("You make me prize things marvelously high: if it were some great science, which were in great demand, you would make it sound very fine: seeing that you prize so highly a mechanical art: which one can easily do without $\left.{ }^{8} . "\right)$

Hands-on experimentation did not begin in the natural scientific laboratory of the nineteenth century; it is instead a characteristic part of craft processes wherever and whenever they have been carried out - whether the bronze hearths of the pre-historic Near East or the furniture ateliers of the Ancien Régime, or in the kilns of the Saintonge, where Palissy labored so hard to imitate porcelain. A contemporary manuscript, BnF Ms. Fr. 640, gives remarkable insight into this constant experimentation of the artisan in the workshop. It also highlights the experimentation on paper that Palissy and other craftspeople engaged in during the sixteenth century (fig. 1). Ms. Fr. 640 came into being in the last decades of the sixteenth century when an anonymous French-speaking practitioner, most likely from the region of Toulouse, took the unusual step of setting down on paper techniques for a number of processes that we would now classify as belonging to the fine arts, crafts and technology: drawing instruction; pigment application; dyeing; coloring of metal, wax, and wood; imitation gem production; metal casting; arms production; tree grafting; land surveying; preservation of animals, plants and foodstuffs; distillation of acids; and much more ${ }^{9}$. The 170 folios with almost 1000 separate entries of this manuscript thus give unique insight into craft and artistic techniques, daily life in the sixteenth century, and material and intellectual understandings of the natural world. Moreover, the manuscript demonstrates the common origins of artistic and scientific innovation in the workshops of early modern Europe, granting an invaluable view into the continuous, methodical experimentation through which art objects were created by skilled labor, and the ways in which the process of artistic creation yielded insights into the behavior of natural materials.

Like Palissy's published works, this compilation of artisanal recipes, observations and experimental notes produced by an experienced practitioner stands at a pivotal moment in the growth of a new mode of gaining knowledge which we now call "empiricism" and "natural science." The fact that an anonymous practitioner recorded technical procedures is part of a seminal development in early modern European history. Until the fifteenth century, craftspeople expressed their knowledge largely in the embodied mastery of techniques and in the objects they produced, but hardly ever in writing. Around 1400, craftspeople increasingly began to turn to writing to record their techniques and make claims for the power and certainty of their knowledge, thus Ms. Fr. 640 is rare evidence from this moment when craft became literate. Such texts were not only experiments in giving voice to the hands, but also experiments on paper of writing down processes that had never before possessed a textual form. Such collections of recipes, so-called "how-to books," began to be widely compiled and disseminated for diverse audiences, and these texts helped to foster a culture that valued practical knowledge.

Scholars have long identified the period from 1400 to 1600 as one in which attitudes toward nature profoundly changed. New theories, practices and materials brought renewed attention to the exploration of nature and to representing it in novel ways, whether through life-like images and objects, mathematical models or measuring instruments. Changing attitudes were accompanied by an explosion of manuscript and printed texts that codified and disseminated new kinds of learning for newly-literate audiences. Palissy's written oeuvre and Ms. Fr. 640 thus represent the intersection of two essential developments in this increase in intellectual and material production: first, the turn to writing down knowledge that had previously been tacit, embodied and 
possessed by skilled craftspeople who learned by making things rather than by reading texts; and second, the move away from reliance on classical textual authorities towards methodical experimentation with natural materials, refining techniques and processes through firsthand experience ${ }^{10}$.

Among such texts of practice, Ms. Fr. 640 is particularly intriguing because it offers unusual insight into daily life and how natural materials and art objects were made, collected, appreciated and circulated in a period of burgeoning production and consumption. Its detailed information about animals and natural materials provides a rare view into vernacular attitudes to nature at the dawn of the "new experimental philosophy" out of which modern science developed. The manuscript is unusual in recording its author's immediate, self-reflexive and iterative notes on various processes for making objects and investigating material properties. It shows the methodical experimentation of the workshop and the ways in which craft was understood as a tool for the investigation of nature.

By the late sixteenth century, such technical writing had become more diverse, with self-aware and assertive artisans such as Palissy striving to be taken seriously as a natural philosopher, giving lectures to learned audiences (by his own report) and publishing books. Where Palissy's books are rhetorically sophisticated and constitute a manifesto for the "vernacular philosophy" of those who work with their hands, Ms. Fr. 640 consists of a clean draft of notes, technical "recipes" and observations collected in the course of making objects and traveling among craft workshops. Although the anonymous author-practitioner of Ms. Fr. 640 may have known the writings of Bernard Palissy, the Toulousain's aims appear to be quite practical and he exhibits no explicitly stylistic nor epistemic ambitions ${ }^{11}$. He was deeply interested and experienced in life casting in a variety of metals, an art form also practiced by the master goldsmith of Nuremberg, Wenzel Jamnitzer (ca. 1508-1585) (fig. 2), and created by a process similar to that by which Palissy and his workshop created the creatures that filled his works of art and that covered the walls of the grottos he constructed for Catherine de Médicis and other nobles in and around Paris (fig. 3).

\section{Casting from Life}

Casting from life is achieved by molding plants, or a recently killed animal, in plaster, burning out or removing the plant or animal (the pattern), then pouring molten metal into the void left by the animal or plant. It is sometimes referred to as lost-pattern (or even lost-lizard) casting ${ }^{12}$. This technique resulted in precise replicas of the cast creature, creating

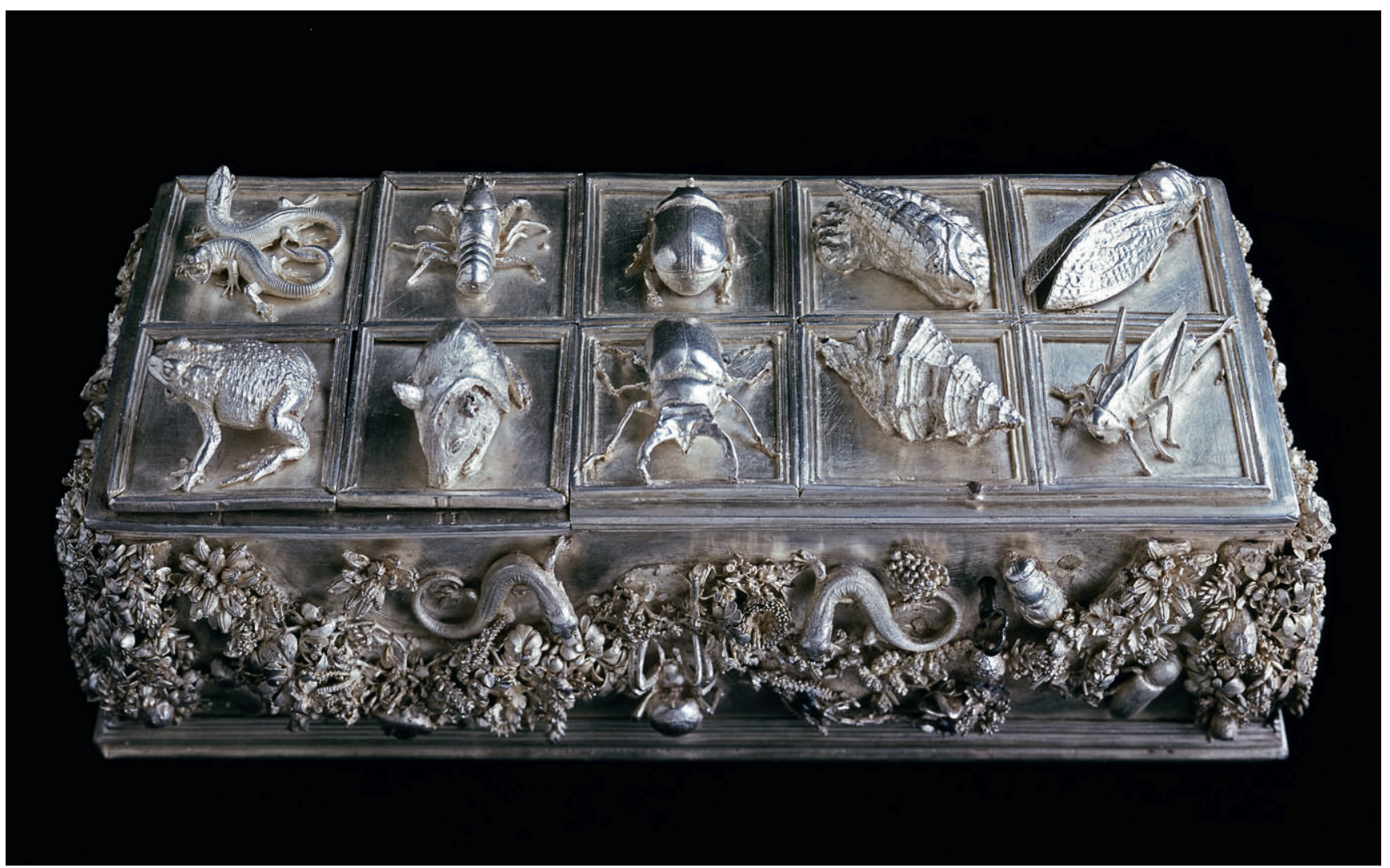

Fig. 2. Wenzel Jamnitzer (attr.), Nuremberg, c. 1560-1570, Writing Box, silver (L. 22,7 cm, B. 10,2 cm, H. 6 cm),

Vienna, Kunsthistorisches Museum, KK 1155. (c) KHM-Museumsverband. 


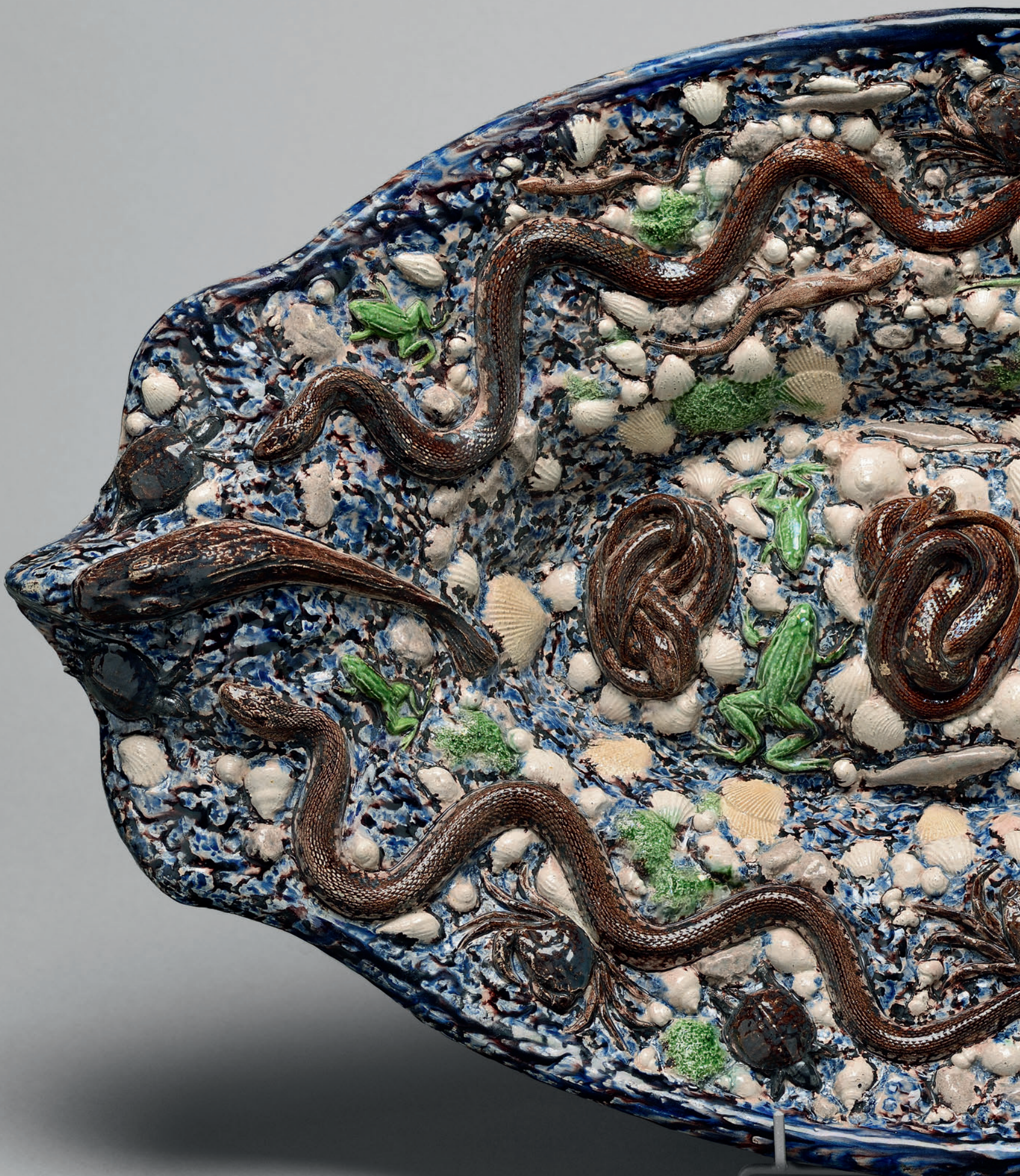

Fig. 3. Bernard Palissy, Saintes (?), c. 1555-1565, Rustic dish, glazed earthenware (B. $45,4 \mathrm{~cm}$, L. 76,1 cm, H. 17,4 cm), Lyon, musée des Beaux-Arts, H 475. @ Musée des Beaux-Arts de Lyon. 


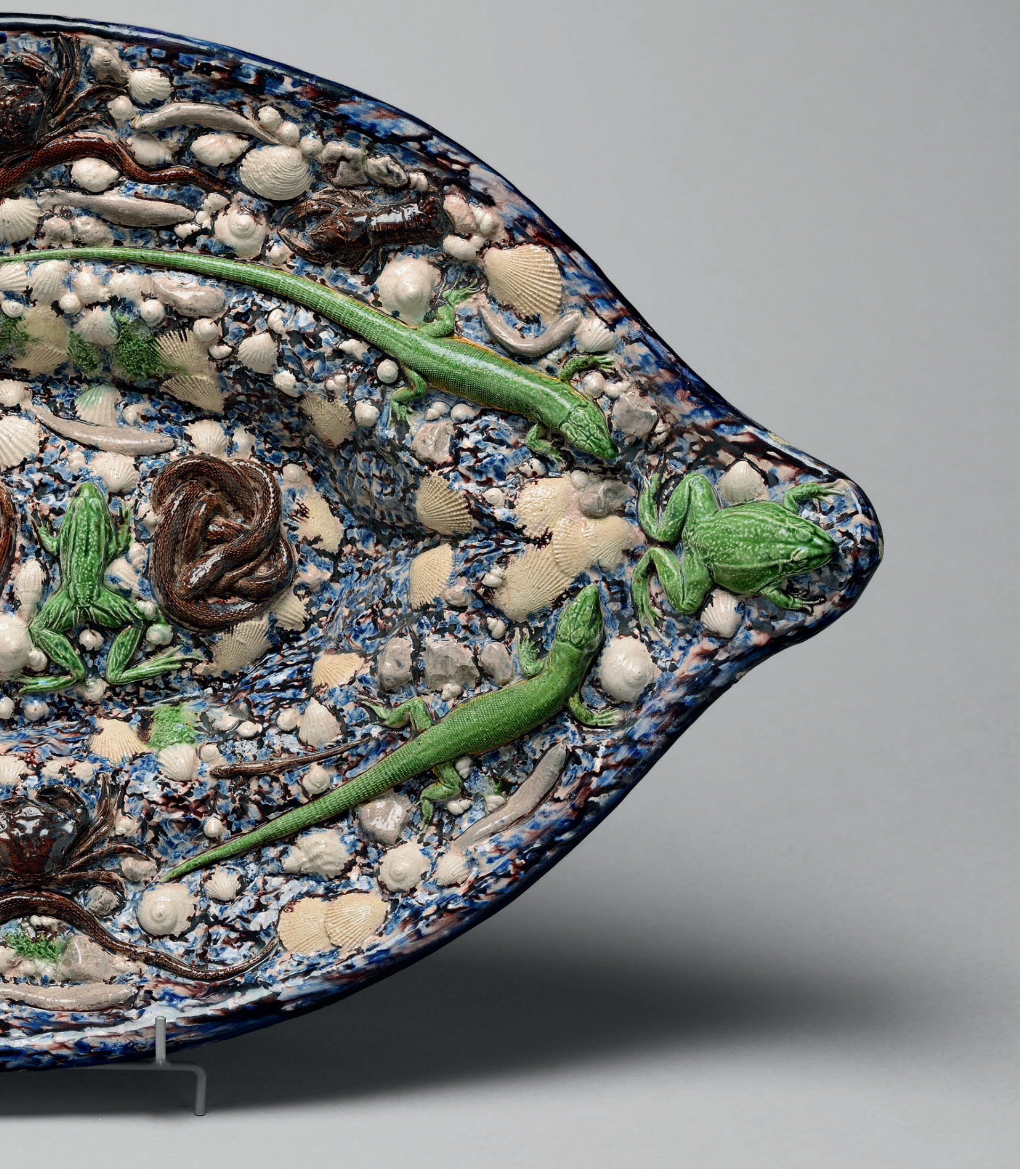


stunningly lifelike objects. Some historians have viewed casting from life as a purely mechanical means of reproduction, however, on the evidence of Palissy's writings and the entries in Ms. Fr. 640, it becomes clear that it is a means not only of producing compelling objects, but also of investigating nature. While Palissy's discourse on the "art of the earth" makes claims for the philosophical knowledge that emerges from his bodily labor, Ms. Fr. 640 provides detailed instructions for catching, keeping, feeding, killing, and finally molding and casting the reptiles, and is filled with "vernacular" natural historical observations and experiments on the behavior of reptiles, as well as numerous accounts of experiments on the behavior of different materials for molding and of metals for casting. We get a sense of the practitioner's

\section{("Snakes for molding}

When you take them for molding, if it is possible, do not remove their teeth if you want to keep them. For, having had their teeth removed, they get sore gums \& mouth, \& can no longer eat. You can keep them in a barrel full of bran or even better of earth, in a cool place, or in a glass bottle. And give them some live frog or other live animal for they eat nothing dead. Also I have noticed that when they want to bite or eat something, they do not bite with a direct attack, but with sinuous turns \& from the side, as do Satan \& his disciples. It has a small head, but a very long body. The entryway to sin seems small \& inconsequential, but the consequences of it are very great. It abstains from eating seven or eight days, once it has devoured some frog. It can swallow three or four of them, one after the other, and what he devoured is neither corrupted nor consumed in one go in its stomach, but any part little by little, that is to say bones and everything. And the remains are found as fresh as when it had devoured them, such that sometimes, when one presses $\&$ torments it, it renders up what it has engulfed, parts of which are found totally consumed \& others as fresh as if it were alive. It can keep for two to three hours a frog engulfed \& renders it up completely alive ${ }^{14}$.”)

\section{Experiment}

Alongside such observations as these on the behavior of snakes, Ms. Fr. 640 contains numerous experiments on materials for molding and casting, on the behavior of plaster, clays, metal alloys, and techniques of firing. The entire manuscript testifies to the extensive experimentation necessary to produce mold material that is fine enough to take the imprint of the animal's or plant's delicate surface texture; light enough not to flatten the animal during molding; durable enough to withstand the burnout, the heating of the mold before casting, and the pouring of the red-hot metal; and friable enough to crumble easily when breaking the mold to reveal the finished cast object. Such qualities could be discovered only by repeated experiment with natural materials. This comes through clearly in the repeated trials of the author of Ms. Fr. 640, who records, for example, that in attempting to identify effective casting ingredients, "ay essaye 4 sortes de sables pour le plomb \& 
estain La croye Le verre pile Le tripoly \& le linge brusle touts 4 fort excellents"15" ("I have tried four kinds of sand for lead \& tin: chalk, crushed glass, Tripoli \& burnt linen, all four excellent"). And on another day "Jay essaye los de pieds de bœuf fort brusle \& pulverise \& broye bien fort sur le porphire jusques a ce quil ne se sente point entre les doigts Il moule tout seul fort net Mays pourceque de soy mesme il est aride \& maigre il veult ester fort mouille \& humecte avecq vin bouilly avecq racine dorme ${ }^{16 "}$ " "I tried the bone of oxen feet, very burned \& pulverized \& ground on porphyry, until it is not felt between your fingers. It molds on its own very neatly. But because on its own it is very arid \& lean, it wants to be well moistened \& dampened with wine boiled with elm root"). Or, "je moulay dos brusle de mache de fer \& feultre brusle fort pulverises \& subtilies sur le mabre et bien mesles ensemble Je les humectay bien fort avecq glaire doeuf battue ${ }^{17}$ " "I molded with burned bone, iron dross \& burned felt, very pulverized $\&$ ground finely on marble and well mixed together. I moistened them very well with beaten egg glair"). One entry records several experiments with what would appear to be local Toulouse sand under the notation "Sables experimentes ${ }^{18}$ ". In some places, he simply notes in the margin: "Essaye" ("Try") ${ }^{19}$, and again in the margin: "Essaye de mesler la ceruse ou minium avecq les aultres sables ${ }^{20 " ~(" T r y ~ t o ~ m i x ~}$ ceruse or minium with the other sands"). Finally, "Le bled orbere faict une pouldre tanee fort subtile \& fort doulce qui estant meslee pourroit mouler fort net Essaye bled en farine brusle a foeu clos Essay"1" ("Orberé wheat makes a tawny powder, very delicate \& very soft, which once mixed could mold very neatly. Try wheat flour burned over a closed fire"). We can see, then, how this practitioner sought out the behavior of natural materials through close observation, and through testing of different materials in order to identify and enhance their properties, aiming to make them function in ways that would produce objects or effects. His repeated testing is echoed in other artisans' manuals, which advise constant trial: "It is necessary to find the true method by doing it again and again... ${ }^{22 " ~ " t o ~ h a v e ~ a ~ s u p e r a b u n d a n c e ~ o f ~}$ tests... not only by using ordinary things but also by varying the quantities, adding now half the quantity of the ore and now an equal portion, now twice and now three times... ${ }^{23}$." The anonymous manuscript Ms. Fr. 640 demonstrates that casting from life (and craft knowledge more generally) was not just productive but also investigative. This investigation extended seamlessly from natural historical observation and experiment to exploration of the properties of stones, woods, metals and all manner of other materials, as well as inquiring into the transformation of matter by means of fire, acid, grinding, crushing and other forms of brute disaggregation.

Bernard Palissy, too, also undertook myriad trials of firing and glazing to produce his extraordinary glazed ceramics, and his works of art were also more than simply a naturalistic representation of these animals; they were rather an investigation of the natural processes that took place in the earth to produce various kinds of earths, minerals and precious materials. In his 1580 Discours admirables, Palissy was particularly concerned with processes of generation, growth and change, and the book as a whole explored springs and waters, ice, salts and their central place in the generation of terrestrial bodies, as well as the generative potential of different earths. In one section of the Admirable Discourses, Palissy makes clear that he discovered and developed his theories about subterranean generation through his experimentation with clays and glazes in producing his life castings, in what he called "the art of the earth." Palissy regarded his "art of the earth" as an investigation of natural processes taking place in the earth, and, through this art, a means to imitate nature and to gain insight into the processes by which stones, earths and all subterranean formations (including what we call fossils) were generated in the earth. He claimed to come to know the workings of nature - its generative powers and forces of transformation - through the bodily experience of imitating it in experiments with clays, sands and salts, and on this basis, he built a philosophy of nature, which he displayed through objects in a museum in Paris, and articulated in his book of 1563, Recepte véritable par laquelle tous les hommes de la France pourront apprendre à multiplier et augmenter leurs thrésors (True Recipe by Which All the Men of France Would be Able to Multiply and Augment Their Treasures), and his 1580 Admirable Discourses ${ }^{24}$.

The beginnings of a philosophy of nature are visible in the testing and trying of sands in Ms. Fr. 640 also, for, through repeatedly trying the properties of the different sands, the author-practitioner is able to generalize about the nature of different sands, and how to modify them: "Despuys jay aperceu que ce sable bien quil soict excelent \& endure beaucoup de gects \& moule bien net Toutesfois il est gras et faict soufler Ainsy le plomb doux ny vient pas si bien Mays essaye de le mesler avecq un sable maigre co[mm]e la ponce lescaille \& semblables pour leur donner corps \& affin quil despouillent mieulx Car les sables maigres ne despouillent gueres bien Et toutesfois ilz recoyvent bien le metal ${ }^{25}$ " ("Since then I have realized that this sand, even though it is excellent \& endures many castings \& molds very neatly, it is however fat and makes things porous. Thus, soft lead does not come out so well. But try to mix it with a lean sand, such as pumice, flakes \& similar things, to give them body \& so that they release better. For lean sands barely release well and yet they receive metal well").

\section{Life casting and Grottos}

Palissy made clear that the grottos and pleasure gardens he designed and built for his noble patrons were not solely places of pleasure, but rather demonstrations, through his ability to recreate a grotto and the freshwater spring it contained, of his understanding of the most fundamental processes of nature. Grottos and their springs were considered primary sites of nature's generative and transformative powers ${ }^{26}$, and their imitation was an attempt to mimic the generative forces of nature. The fact that Palissy placed his life cast animals in his famed grottos indicates meaningful dimensions to these 


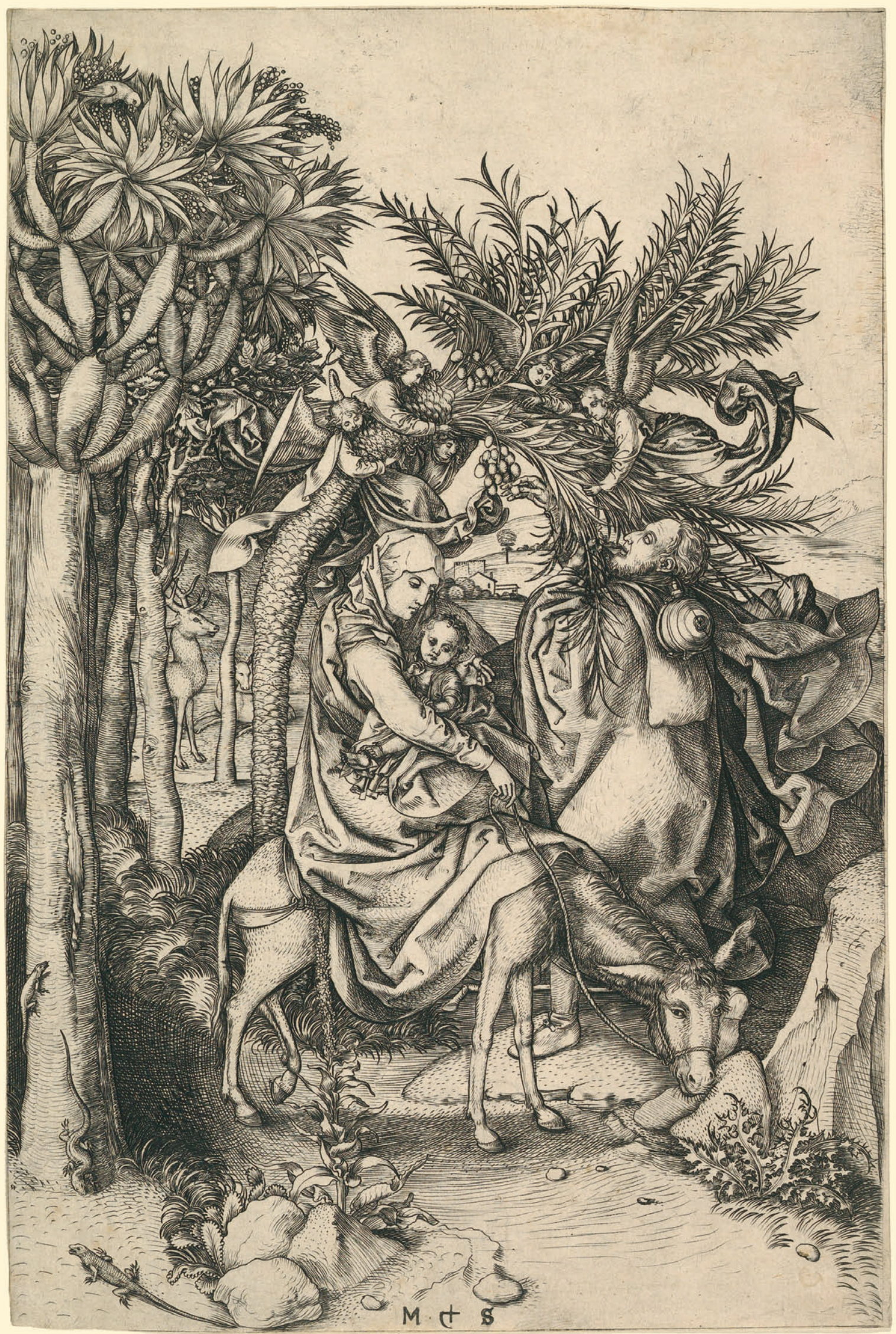

Fig. 4. Martin Schongauer, c. 1470, The Flight into Egypt, engraving (B. 16,8 cm, L. 25,3 cm), New York, Metropolitan Museum of Art, Harris Brisbane Dick Fund, 1929, 29.48.1. Lower left: Lizards climb the "Dragon Tree" from which a red healing resin,

"Dragonsblood", is obtained. Met Museum CC License/Public Domain. 
liminal creatures. The precise imitation through casting from life not only allowed the artisan to come to knowledge of these creatures through observing, investigating and imitating, but also connected the artisan to the powers of nature and therefore to the divine plan of God's Creation ${ }^{27}$. For example, lizards in Schongauer's engraving The Flight to Egypt, climb up a dragon tree ${ }^{28}$ (fig. 4). Schongauer's engraving is the first European source to describe the dragon tree, native to the Canary islands and north Africa, visually or in writing, although the sap - dragonsblood - had been known in Europe since the Middle Ages as a means to stop the flow of blood and eventually as an ingredient in printers' in ${ }^{29}$. In a woodcut of the same Christian subject, Albrecht Dürer portrayed lizards near a spring, the source of generation, past which the holy family journeys. Lizards in these two prints are associated with healing, protection, generative springs and divine events.

These two prints demonstrate aspects of the spiritual meanings of lizards, but these reptiles also possessed phenomenological significance. For these are what we call amphibious animals and, within the early modern cosmos based on the four elements, these creatures all inhabited more than one elemental zone: lizards, snakes, toads and crabs lived both on land and in water, and insects and birds inhabited both air and land, and often water too. In addition, many of the creatures employed in life casting could be found creeping on the earth, having appeared seemingly spontaneously from putrefying matter. Lizards, snakes, frogs, toads, turtles and all kinds of insects often appeared around carcasses, in warm, wet and muddy conditions, and swarmed around putrefying matter. Their presence in these conditions gave support to the commonsense principle that they were generated in wet, fertile sites, teeming with life, and that their emergence involved processes of decay through which new life came to be generated. Furthermore, many of the reptiles and insects recalled processes of transformation and the ephemeral nature of life on earth and its processes of coming into being and passing away. Insects metamorphosed, lizards regenerated their tails when they lost them, snakes shed their skins, adult frogs and turtles emerged from the ground after freezing winters, and crustaceans were reported to be found alive in solid stone well into the eighteenth century ${ }^{30}$. In other words, the types of animals used for life casting could give insight into processes of putrefaction, transformation, generation and regeneration ${ }^{31}$. These animals were sometime viewed as impure and associated with putrefaction, yet also as crucial in processes of transformation and generation, such as birth ${ }^{32}$.
The sixteenth-century metalworker Vannoccio Biringuccio makes explicit the reasons that Palissy and the anonymous sixteenth-century practitioner of Ms. Fr. 640 collected and cast these types of animals: Biringuccio viewed nature as full of divine powers, writing that all things created by God have some particular gift or power. If we humans cannot see it, it lies in our "defective vision, in our little knowledge, and in our lack of careful thought concerning the necessity of seeking hidden things." He wrote that "those things that have such inner powers, like herbs, fruits, roots, animals, precious stones, metals or other stones, can be understood only through oft-repeated experience ${ }^{33}$." Artisans sought to observe, investigate and imitate nature in order to discover and employ the powers that inhered in nature, powers that gave access both to natural and divine knowledge.

\section{Life casting and the New Philosophy}

The anonymous author-practitioner of Ms. Fr. 640, Wenzel Jamnitzer, and Bernard Palissy all created their casts from life for the Kunstkammer, in which objects demonstrating the artifice of God's creation sat beside, or were combined with, creations resulting from the artifice of the human hand. For Jamnitzer and Palissy, the ambition to mimic nature with such verisimilitude was not just a virtuoso display, but also demonstrated their understanding of the most fundamental processes of nature. Thus, life casting, among other making techniques, suggested that imitation through the work of the human hand was a means to know nature. Indeed, about a century later, Gottfried Wilhelm Leibniz (1646-1716) noted that the process of fossilization could be explained by observing the technique of casting from life: "We find something similar in the art of the goldsmith, for I gladly compare the secrets of nature with the visible works of men. They cover a spider or some other animal with suitable material, though leaving a small opening, they drive the animal's ashes out through the hole, and, finally, they pour silver in the same way. When the shell is removed, they uncover a silver animal, with its entire complement of feet, hairs, and fibers, which are wonderfully imitated $^{34}$." For Leibniz, as for many other late seventeenthcentury natural philosophers, knowing the processes of nature had become synonymous with knowing how to imitate nature in the making of things. In the seventeenth century, many self-described "new experimental philosophers" began to revise Aristotle's definition of knowing as the knowledge of causes, and to declare instead that "making was knowing," that is, a made thing was a known thing and, by extension, that the harnessing of natural processes to produce objects and effects was to know those processes, objects and effects. 


\section{Making, Writing and Knowing}

The author-practitioner of Ms. Fr. 640 seems to have set down his text incrementally in a fair copy, followed by more experimentation, which gave rise to new ideas, followed by further observations and trials, all recorded in increasingly cramped script in the margins, indeed, in any available space in the manuscript. It appears that the author-practitioner's composition of the manuscript could not be divorced from practicing in his workshop. The text enacts the trying again and again of the author-practitioner, and the essential need to proceed in gaining an understanding of materials and processes by what we would call the method of "experimentation." Palissy's texts also re-enact in words his processes of bodily labor, experiment and creation. Like other artisans writing at this time, Palissy and Ms. Fr. 640's author-practitioner were engaged not only in hands-on work, but also in experimentation on paper. Palissy had his protagonists, Theorique and Practique, engage in polemic, without providing much specific detail about his actual recipes and techniques; Palissy was explicit about his natural philosophical aims, but meagre on specifics. In contrast, Ms. Fr. 640 contains a record of many very detailed processes with no evident trace of rhetorical or stylistic striving. Ms. Fr. 640 thus makes explicit the constant investigation in which both Palissy and the anonymous practitioner engaged. And, while not proclaimed in the same terms as Palissy, it is also possible to extract from the account of Ms. Fr. 640's materials and processes the underlying formation of a philosophy of nature.

For the historian of science, both authors present challenges of decipherment. It became clear in researching Ms. Fr. 640 that understanding its detailed, iterative and often confusing instructions could not be separated from actually trying out the methods recorded in it: "reading" the text for meaning and understanding had to involve "reconstructing the actions" described in it. Thus in 2014, I founded a large collaborative research and pedagogical initiative, the Making and Knowing Project (www.makingandknowing.org) to explore historical and methodological intersections between artistic making and scientific knowing, such as that demonstrated in Ms. Fr. 640.

\section{The Making and Knowing Project}

$\mathrm{F}$ ROM 2014 through 2019, the Project is creating a digital critical edition of this intriguing manuscript, bringing together a myriad of collaborators in the humanities, art, and natural sciences at institutions worldwide who are carrying out interdisciplinary research, teaching and knowledge exchange about the text and its processes. The publication of the finalized transcription and English translation of Ms. Fr. 640 as a digital scholarly edition at the end of 2019 will make accessible a remarkable source that will significantly enhance the existing body of early modern technical writing, and allow readers to understand and analyze the actions of craft making as the creation of empirically-tested knowledge about the natural world. Moreover, as the Project's initial research and dissemination has already shown, it will engage readers, whether researchers, students or the broader public, in a new approach to exploring historical texts, one which emphasizes the importance of the material conditions, interpretations and outcomes that emerge when the written word is realized through investigations into matter. The manuscript codifies procedures that were not meant to be reproduced solely through the act of reading, but were an invitation to engage in hands-on practice, and to imitate and experiment. The edition will, in turn, through its critical commentary and accompanying videos and visual resources, invite its audience not only to read and analyze the text but also to explore and investigate the materials and processes detailed within it. Perhaps such an intention also impelled the writings of Palissy and the anonymous author of Ms. Fr. 640. 
Endnotes

1. Palissy, 2010, p. 487.

2. Ibid., p. 489

3. Palissy, 1957, p. 193-194.

4. Ibid., p. 195

5. Palissy, 2010, p. 497.

6. Palissy, 1957, p. 201.

7. Palissy, 2010, p. 497.

8. Palissy, 1957, p. 202.

9. For more information on BnF Ms. Fr. 640, see The Making and Knowing Project (www.makingandknowing.org), and the articles resulting from the Project's research, including Bilak, Boulboullé, Klein, Smith, 2016; Smith and The Making and Knowing Project, 2016. Although the genesis of the manuscript cannot be reconstructed in its entirety, it is clear from the many references to Toulouse and surroundings, as well as references to individuals living in Toulouse in the last 30 years of the sixteenth century, that the practitioner knew Toulouse and some of its inhabitants well.

10. On these developments, see Smith, 2004, Smith, forthcoming and the work of Long, especially 2011.

11. Palissy's name is mentioned with his title "Mestre Bernard palissi inventeur des rustiques figulines du roy et de la royne mere" which is what Palissy calls himself (without "maistre" and with a minor variant: "...royne sa mere") on the title page of his Discours admirables published in Paris by Martin Le Jeune in 1580

12. Techniques of life casting did not always necessitate the loss of the mold, nor of the pattern. On life casting, see Smith and Beentjes, 2010, and further references cited there.

13. BnF Ms. Fr. 640, fols. $109^{r}{ }^{r}$

14. All translations of Ms. Fr. 640 are the outcome of five years' of collective work by students and other collaborators of the Making and Knowing Project. For a list of all translators, see https://www. makingandknowing.org/text-workshops/ paleography-workshop-participants/.

15. BnF Ms. Fr. 640, fol. $68^{\text {r }}$

16. BnF Ms. Fr. 640 , fol. $86^{\mathrm{r}}$

17. BnF Ms. Fr. 640, fol. $86^{\mathrm{v}}$

18. BnF Ms. Fr. 640 , fol. $85^{\mathrm{v}}-86^{\mathrm{v}}$.

19. BnF Ms. Fr. 640 , fol. $131^{\mathrm{r}}$.

20. BnF Ms. Fr. 640 , fol. $85^{\mathrm{r}}$ (in the margin).

11. BnF Ms. Fr. 640 , fol. $88^{\mathrm{v}}$ (in the margin).

22. Biringuccio, 1966, p. XVI.

23. Biringuccio, 1966, p. 143-144

24. On Palissy, see Amico, 1996.

25. Ms. Fr. 640 , fol. $84^{\mathrm{v}}$.

26. Bredekamp, 1995 and Morel, 1990.

27. I made the following points in somewhat briefer form in Smith, 2004.

28. Krohm, Nicolaisen, 1991, p. 83-84, no. 3c (Lehrs 7). See Koch, 1976; also Pochat, 1970, p. 118-36; and Eisler, 1991, p. 133.

29. For example, the entry in Ms. Fr. 640 , fol. $38^{\mathrm{v}}$ "Against nosebleed and for dyeing".
30. In the sixteenth century, see Agricola, 1961, p. 196-197, in which he talks about the creatures found in shafts, and cracks in the rock, indeed, in places in rocks that seem to have no openings. He notes that they have been found in Schneeberg and Mansfeld. When they are brought out from underground, they puff themselves up then die. These are found especially around Toulouse in the red, white-flecked sandstone from which millstones are made. Thus one must always break the stone before making millstones because if the toad gets warm with the action of the millstone, it puffs itself up, breaks the rock and poisons the grain.

31. Smith, 2004, p. 117-123. See also Leonhard, 2009-2010, who provides an excellent survey of interest in spontaneous generation in the seventeenth century, p. 103ff. Modern scientists are still interested in the properties of lizard tails that allow them to regenerate.

32. Evidence for the ambivalent attitude toward frogs and toads as implicated both in harmful evildoing and beneficial fertility can be found in Wilson, 2000, p. 150 and p. 417-420. Metamorphosis of butterflies from pupae and other processes of transformation were taken as evidence of the possibility of resurrection: see CrowtherHeyck, 2003, p. 266.

33. Biringuccio, 1966, p. 114; See also Crowther-Heyck, 2003, on the fundamental connection in early modern Europe that existed between studying created nature and piety. As Jacob Horst in 1579 wrote: "although God is invisible... He can be recognized and understood through the natural creations and through the earth, which is so exquisitely made." Jakob Horst, Von den Wunderbarlichen Geheimnissen der Natur (Lepizig: Hansz Steinman, 1579), sig. Bvi, cited in Crowther-Heyck, 2003, p. 263. See also Crowther, 2010.

34. Leibniz, 2008.

\section{Bibliography}

Agricola G., 1961, De Animantibus Subterraneis Liber (1549, revised 1556), Ausgewählte Werke, trans. G. Fraustadt and R. Hertel, Deutscher Verlag der Wissenschaften, Berlin.

Amico L., 1996, Bernard Palissy: In Search of Earthly Paradise, Flammarion, Paris.

Anonymous, Ms. Fr. 640, Bibliothèque nationale de France, Paris.

Bilak D., Boulboullé J., Klein J., Smith P. H., 2016, "The Making and Knowing Project - Reflections, Methods, and New Directions", New Directions in Making and Knowing, Special Issue of West 86th: A Journal of Decorative Arts, Design History, and Material Culture, 23.1, p. 35-55.

Biringuccio V., 1966, Pirotechnia (1540), trans. C. S. Smith and M. T. Gnudi, Harvard University Press, Cambridge.

Bredekamp H., 1995, The Lure of Antiquity and the Cult of the Machine, trans. A. Brown, Markus Wiener publishers, Princeton.
Crowther K., 2010, Adam and Eve in the Protestant Reformation, Cambridge University Press, Cambridge.

Crowther-Heyck K., 2003, "Wonderful Secrets of Nature: Natural Knowledge and Religious Piety in Reformation Germany," Isis, 94.2, p. 253-273.

Eisler C., 1991, Dürer's Animals, Smithsonian Institution Press, Washington D.C.

Koch R., 1976, “Schongauer's Dragon Tree”, Print Review 5, p. 114-119.

Krohm H., Nicolaisen J., 1991, Martin Schongauer, Druckgraphik Staatliche Museen, Berlin.

Leibniz G. W., 2008, Protogaea, trans. and ed C. Cohen and A. Wakefield, University of Chicago Press, Chicago.

Leonhard K., 2009-2010, "Pictura's fertile field: Otto Marseus van Schrieck and the genre of sottobosco painting", Simiolus: Netherlands Quarterly for the History of Art, 34, n ${ }^{\circ}$, p. 95-118.

Long P. O., 2011, Artisan Practitioners and the Rise of the New Sciences, 1400-1600, Oregon State University Press, Corvallis.

Making and Knowing Project, www.makingandknowing.org.

Morel P., 1990, "La théâtralisation de l'alchimie de la nature. Les grottes artificielles et la culture scientifique à Florence à la fin du xvi ${ }^{\mathrm{e}}$ siècle", Symboles de la Renaissance, 30, Rue d'Ulm, Paris, p. 155-181.

Palissy B., 1957, The Admirable Discourses (1580), trans. A. la Rocque, University of Illinois Press, Urbana.

Palissy B., 2010, Euvres complètes, M.-M. Fragonard (dir.), seconde édition revue et annotée, Honoré Champion, Paris.

Pochat G., 1970, Der Exotismus während des Mittelalters und der Renaissance, Almqvist and Wiksell, Stockholm.

Smith P. H., 2004, The Body of the Artisan: Art and Experience in the Scientific Revolution, University of Chicago Press, Chicago.

Smith P. H., Beentjes T., 2010, "Nature and Art, Making and Knowing: Reconstructing Sixteenth-Century Life Casting Techniques", Renaissance Quarterly, vol. 63, n 1 , p. 128-179.

Smith P. H. and the Making and Knowing Project, 2016, "Historians in the Laboratory: Reconstruction of Renaissance Art and Technology in the Making and Knowing Project", Art History, 39.2, p. 210-233.

Smith P. H., forthcoming, From Lived Experience to the Written Word: Recovering Art and Skill in Early Modern Europe, University of Chicago Press, Chicago.

Wilson S., 2000, The Magical Universe: Everyday Ritual and Magic in Pre-Modern Europe, Hambledon, London. 